\title{
PENGARUH INFLASI, SUKU BUNGA DAN NILAI TUKAR TERHADAP HARGA SAHAM STUDI KASUS PADA PERUSAHAAN MANUFAKTUR OTOMOTIF TERDAFTAR DI BURSA EFEK INDONESIA TAHUN $2012-2017$
}

\author{
Ridwan Maronrong $^{1}$, Kholik Nugrhoho ${ }^{2}$ \\ Sekolah Tinggi Ilmu Ekonomi Indonesia \\ Jl. Kayu Jati Raya No. 11A, Rawamangun - Jakarta 13220, Indonesia \\ ridwanmaronrong@yahoo.com ${ }^{1}$,kholik31@ gmail.com ${ }^{2}$
}

\begin{abstract}
Abstrak - Penelitian ini bertujuan untuk menguji pengaruh Inflasi, Suku Bunga dan Nilai Tukar terhadap Harga Saham studi kasus pada perusahaan manufaktur otomotif terdaftar di bursa efek indonesia tahun 2012 - 2017, baik secara simultan maupun parsial. Penelitian ini menggunakan metode pendekatan kuantitatif. Sampel penelitian yang digunakan yaitu PT. Astra Internasional Tbk. dan PT. Indomobil Sukses Internasional Tbk.. Data yang digunakan adalah data selama 6 tahun yaitu dari tahun 2012 sampai dengan 2017. Data kuantitatif yang digunakan dalam penelitian adalah data inflasi, suku bunga, nilai tukar dan harga saham PT. Astra Internasional Tbk. dan PT. Indomobil Sukses Internasional Tbk. dengan data per bulan. Teknik analisis data yang digunakan yaitu analisis regresi liniear berganda menggunakan SPSS 24.00. Pengujian hipotesis menggunakan uji t (uji parsial) dan Uji F (uji simultan). Hasil penelitian menunjukkan bahwa secara parsial Inflasi dan Suku Bunga tidak berpengaruh signifikan terhadap harga saham dan Nilai Tukar berpengaruh terhadap harga saham PT. PT. Astra Internasional Tbk. dan PT. Indomobil Sukses Internasional Tbk. tahun 2012-2017, sedangkan secara simultan menunjukkan bahwa Inflasi, Suku Bunga, dan Nilai Tukar berpengaruh signifikan terhadap harga saham PT. PT. Astra Internasional Tbk. dan PT. Indomobil Sukses Internasional Tbk. tahun 2012-2017.
\end{abstract}

\section{Kata kunci : Inflasi, Suku Bunga, Nilai Tukar, Harga Saham}

\section{PENDAHULUAN}

Saat ini perkembangan investasi di suatu negara dipengaruhi oleh pertumbuhan ekonomi di negara tersebut. Semakin baik tingkat pertumbuhan ekonomi di Negara tersebut semakin baik pula tingkat kesejahterahan hidup masyarakatnya. Masyarakat hidup sejahtera biasanya ditandai dengan kenaikan tingkat pendapatannya. Saat masyarakat memiliki tingkat pendapat yang tinggi, maka masyarakat akan cenderung mempunyai dana yang lebih. Dana yang lebih tersebut bisa dimanfaatkan sebagian untuk berinvestasi di tabungan maupun di dunia saham. 
Sektor industri otomotif di Indonesia masih menjadi tempat investasi yang menguntungkan bagi investor karena industri ini terus tumbuh setiap tahunnya dan investasi di dalam sektor industri otomotif akan dipengaruhi oleh faktor - faktor makroekonomi. Faktor makroekonomi yang dapat mempengaruhi kinerja saham maupun kinerja perusahaan antara lain : inflasi, tingkat suku bunga dan kurs (nilai tukar valuta asing).

Peningkatan laju kenaikan inflasi yang tinggi pada umumnya diiringi dengan meningkatnya tingkat suku bunga untuk mengurangi penawaran uang berlebih. Kecenderungan naiknya harga barang dan jasa pada umumnya yang berlangsung secara terus menerus. Jika inflasi meningkat, maka harga barang dan jasa di dalam negeri mengalami kenaikan. Naiknya harga barang dan jasa tersebut menyebabkan turunnya nilai mata uang. Di sisi lain, meningkatnya suku bunga merupakan peluang investasi yang cukup menjanjikan bagi investor, suku bunga akan berdampak pada harga saham di pasar modal.

Perkembangan pasar saham suatu Negara erat kaitannya dengan fluktuasi faktor makroekonomi, dimana variable - variabel makroekonomi baik nasional maupun internasional, mempengaruhi prospek export - import, serta kompetisi harga dari pesaing di tingkat local maupun mancanegara, dan hal ini tentunya akan mempengaruhi prospek pertumbuhan perusahaan. Tetapi, walaupun faktor ekonomi global itu penting, namun kinerja ekonomi di berbagai Negara sangat bervariasi, selain itu lingkungan ekonomi global memiliki berbagai risiko, mulai risiko perubahan politik, nilai tukar, suku bunga serta risiko lainnya.

\subsection{Perumusan Masalah}

Dari latar belakang masalah diatas, maka perumusan masalah yang diangkat dalam penelitian ini adalah: Apakah inflasi, suku bunga dan nilai tukar berpengaruh terhadap harga saham perusahaan manufaktur yang terdaftar di Bursa Efek Indonesia pada tahun $2012-2017 ?$

\subsection{Tujuan Penelitian}

Tujuan dari penelitian ini adalah: untuk mengetahui berapa besar pengaruh antara inflasi, nilai tukar dan suku bunga terhadap harga saham perusahaan manufaktur yang terdaftar di Bursa Efek Indonesia.

\subsection{Manfaat Penelitian}

Berikut ini manfaat bagi kalangan :

1. Peneliti : memperluas wawasan berpikir, dan sebagai bahan pertimbangan sampai sejauh mana teori - teori yang didapat selama masa perkuliahan dapat diterapkan didunia kerja sesungguhnya.

2. Investor : menjadi salah satu dasar pertimbangan dalam mengambil keputusan dalam bidang keuangan terutama dalam rangka meningkatkan harga saham yang dimiliki oleh Investor.

3. Mahasiswa : dapat memberikan wawasan, pengetahuan, menambah referensi informasi, dan memberikan pembuktian tentang pengaruh inflasi, suku bunga dan nilai tukar terhadap harga saham serta bermanfaat untuk penelitian dimasa yang akan datang. 


\section{KAJIAN PUSTAKA}

\subsection{Review Hasil-hasil Penelitian Terdahulu}

$>$ Penelitian pertama yang dilakukan oleh Yeny Nur Khasanah dan Ari Darmawan dalam Jurnal Administrasi Bisnis (JAB) ISSN 1411-0393, Vol. 57 No.1, April 2018, Universitas Brawijaya, Jawa Timur dengan judul "Pengaruh Risiko Inflasi, Risiko Suku Bunga, Risiko Kurs Valuta Asing, Dan Leverage Terhadap Return Saham" (Studi Pada Industri Manufaktur Sub Sektor Otomotif Dan Komponen Yang Terdaftar Di Bursa Efek Indonesia Periode 2006-2016). Variabel yang digunakan dalam jurnal ini adalah inflasi, suku bunga, kurs valuta asing, leverage serta harga saham. Penelitian ini menggunakan metode analisis regresi linier berganda.

> Penelitian kedua yang dilakukan oleh Suskim Riantani dan Maria Tambunan dalam Seminar Nasional Teknologi Informasi \& Komunikasi Terapan 2013 (SEMANTIK 2013), ISBN: 979-26-0266-6, November 2013, Universitas Widyatama Bandung, Semarang dengan judul "Analisis Pengaruh Variabel Makroekonomi dan Indeks Global terhadap Return Saham pada Industri Otomotif". Variabel yang digunakan dalam penelitian ini adalah Variabel makroekonomi diukur melalui kurs rupiah per dollar AS, suku bunga SBI, inflasi, sedangkan indeks global diukur melalui indeks Hang Seng dan indeks Dow Jones. Penelitian ini menggunakan metode analisis regresi linier berganda.

$>$ Penelitian Ketiga yang dilakukan oleh Muhammad Arif Falilah dan Sri Hermuningsih dalam Journal Manajemen Dewantara Vol 1. No 2, 2017, e-ISSN 2579-4612, Universitas Sarjahawiyata Tamansiswa, Jogjakarta dengan judul "Pengaruh Nilai Tukar dan Harga Minyak Mentah Dunia Terhadap Return Saham PT. Indomobil Sukses Internasional Tbk. Dan PT. Astra Internasional Tbk. Tahun 2006-2016". Variabel yang digunakan dalam penelitian tersebut adalah Nilai Tukar, Harga Minyak Mentah Dunia, dan Return Saham. Alat analisis yang digunakan adalah teknik analisis regresi linier berganda.

> Penelitian keempat yang dilakukan oleh Jaja Suteja dan Patrisius Seran dalam Trikonomika Volume 14, No. 1, Juni 2015, ISSN 2355-7737, Universitas Pasundan, Jawa Barat, dengan judul "Determinan Return Saham Industri Otomotif dan Komponen yang Terdaftar di BEI". Variable yang digunakan dalam penelitian ini adalah Return on Equity (ROE), Debt to Equity Ratio (DER), Net Profit Margin (NPM), inflasi, nilai tukar, dan suku bunga terhadap return saham Industri Otomotif dan Komponen. Alat analisis yang digunakan adalah regresi panel..

$>$ Penelitian kelima yang dilakukan oleh Muhammad Paizal dalam Jurnal Online Mahasiswa Bidang Manajemen, Vol 1 No. 1, 2017, 2407-8565, dengan judul "Pengaruh Makro Ekonomi dan Mikro Perusahaan Terhadap Harga Saham Perusahaan Sub Sektor Otomotif yang Terdaftar di Bursa Efek Indonesia Periode 2012-2015". Variable yang digunakan penulis dalam penelitiannya adalah Makro Ekonomi (Inflasi, Nilai Tukar) dan Mikro Perusahaan (Return On Equity, Debt to Equity Ratio, Earning Per Share). Penelitian ini menggunakan metode analisis regresi linier berganda.

> Penelitian keenam yang dilakukan oleh Rim M. El Khoury dalam Jurnal Ekonomi dan Keuangan Internasional, ISSN 1752-0479, dengan judul "Do macroeconomic factors matter for stock returns? Evidence from the European automotive insdustri", variabel yang digunakan penulis dalam penelitiannya adalah variabel Makroekonomi. 
$>$ Penelitian ketujuh yang dilakukan oleh Tantri Bararoh dalam Jurnal Investasi dan Manajemen Internasional, ISSN (Online): 2328-7721, Bangladesh, India dengan judul "Impact of Macroeconomic Variables on Stock Returns: Evidence from Bombay Stock Exchange (BSE)". Tujuan dari makalah ini adalah untuk menggabungkan faktor global dan domestik dan memperluas hubungan yang diduga antara pengembalian saham dan variabel ekonomi makro ke pasar negara berkembang di India. Menggunakan analisis deret waktu, makalah ini mempekerjakan

> Penelitian kedelapan yang dilakukan oleh Petr Pavlı'nek dan Jan Z ` enka dalam Jurnal Environment and Planning Vol. 48(5) 937-959, 2016, Amerika Serikat, dengan judul "Value creation and value capture in the automotive insdustri: Empirical evidence from Czechia". Dalam jurnal diatas, penulis menetapkan untuk mengevaluasi nilai cipta dan nilai tangkap dalam insdustri otomotif yaitu berbagai tingkatan perusahaan otomotif. Analisis data dari insdustri otomotif Ceko, hipotesis pertama bahwa perusahaan yang besar menghasilkan pendapatan lebih besar daripada perusahaan kecil. Akibatnya pangsa pasar mereka dari total nilai tambah di industri otomotif semakin meningkat. Sedangkan hipotesis kedua bahwa pemasok dalam negeri mengimpor bagian input yang lebih rendah daripada pemasok asing. Hipotesis ketiga yaitu bahwa perusahaan yang besar mengimpor input lebih rendah daripada perusahaan kecil dikonfirmasi untuk perusahaan asing bukan di dalam negeri. Hipotesis keempat penulis berpendapat bahwa perusahaan besar memiliki kompetensi yang lebih kuat dan lebih beragam daripada perusahaan yang dibawahnya.

\subsection{Landasan Teori}

\subsubsection{Inflasi}

a. Definisi Inflasi yang dikemukakan oleh Bodie Kane Marcus (2014:141) adalah tingkat kenaikan harga secara umum. Tingkat inflasi yang tinggi sering diasosiasikan dengan ekonomi yang "terlalu panas", yaitu ekonomi dimana permintaan barang dan jasa lebih tinggi dari kapasitas produksi, sehingga terjadi kenaikan harga - harga.

b. Menurut Badan Pusat Statistik (BPS), inflasi merupakan kecenderungan naiknya harga barang dan jasa pada umunya yang berlangsung secara terus menerus. Jika inflasi meningkat, maka harga barang dan jasa tersebut menyebabkan turunnya nilai mata uang.

c. Menurut Blanchard dan Johnson (2016,39), inflasi diartikan sebagai kenaikan bertahap atas tingkat harga secara umum dan tingkat inflasi diartikan sebagai tingkat harga meningkat.

Menurut Sukirno (2013:339), faktor - faktor yang menjadi pemicu inflasi adalah :

1. Demand pull Inflation, terjadi apabila sektor perusahaan tidak mampu dengan cepat melayani permintaan masyarakat terhadap barang berwujud didalam pasar. Masalah kekurangan barang akan berlaku dan ini akan mendorong kepada kenaikan harga - harga. Inflasi karena permintaan biasanya akan berlaku ketika perekonomian berjalan dengan pesat.

2. Cost push Inflation, adalah masalah kenaikan harga - harga dalam perekonomian yang diakibatkan oleh kenaikan biaya produksi. Pertambahan biaya produksi akan mendorong perusahaan-perusahaan menaikkan harga, walaupun harus 
mengambil resiko akan mengahadapi pengurangan dalam permintaan barangbarang yang diproduksinya.

\subsubsection{Nilai Tukar}

a) Pendapat yang dikemukan oleh Mankiw-Quah Wilson (2014:32), nilai tukar dibagi menjadi dua, yaitu nilai tukar nominal diartikan sebagai nilai yang digunakan seseornag saat menukar mata uang suatu Negara dengan mata uang negara lain. Sedangkan nilai tukar riil diartikan sebagai nilai yang digunakan oleh seseorang saat menukarkan barang dan jasa dari suatu Negara dengan barang dan jasa dari Negara lain.

b) Menurut Hamdy dalam buku Economics, Pengantar Mikro/Makro, Iskandar Putong (2013:366) menyatakan bahwa valuta asing / foreign exchange adalah mata uang asing atau alat pembayaran lainnya yang digunakan untuk melakukan atau membiayai transaksi ekonomi keuangan internasional dan yang mempunyai catatan kurs resmi pada bank central.

Faktor-faktor yang dapat mempengaruhi kurs menurut Sukirno (2013) sebagai berikut:

1. Perubahan dalam cita rasa masyarakat akan mengubah corak konsumsinya atas barang-barang yang di produksi di dalam maupun luar negeri. Perbaikan kualitas barang-barang dalam negeri menyebabkan keinginan mengimpor berkurang dan juga dapat menaikkan ekspor.

2. Perubahan harga barang ekspor dan impor. Barang-barang dalam negeri yang dapat dijual dengan harga relatif murah akan menaikkan ekspor dan apabila harganya naik maka ekspor akan berkurang. Pengurangan harga barang impor akan menambah jumlah impor dan kenaikan harga barang impor akan mengurangi impor. Dengan demikian perubahan harga barang ekspor dan impor akan menyebabkan perubahan dalam permintaan dan penawaran valuta asing.

3. Kenaikan harga umum (inflasi). Inflasi sangat besar pengaruhnya terhadap kurs pertukaran valuta asing. Inflasi pada umumnya cenderung menurunkan nilai valuta asing.

4. Perubahan suku bunga dan tingkat pengembalian investasi. Suku bunga dan tingkat pengembalian investasi yang rendah cenderung akan menyebabkan modal dalam negeri mengalir keluar negeri sedangkan suku bunga dan tingkat pengembalian investasi yang tinggi akan menyebabkan modal luar negeri akan masuk ke dalam negeri.

5. Pertumbuhan ekonomi suatu Negara. Efek yang akan ditimbulkan oleh suatu kemajuan ekonomi kepada nilai mata uangnya tergantung pada pertumbuhan ekonomi yang terjadi. Apabila kemajuan ekonomi diakibatkan oleh perkembangan ekspor, maka permintaan atas mata uang asing akan bertambah lebih cepat dari penawarannya sehingga mata uang tersebut akan naik.

\subsubsection{Suku Bunga}

$>$ Menurut Kasmir (2014:114) bunga bank dapat diartikan balas jasa yang diberikan oleh bank yang berdasarkan prinsip konvensional kepada nasabah yang membeli atau menjual produknya. Bunga juga bisa diartikan harga yang harus dibayar kepada nasabah dengan yang harus dibayar oleh nasabah kepada bank.

$>$ Sedangkan menurut Ross (2015:68) suku bunga dibedakan antara suku bunga riil dan suku bunga nominal. Suku bunga nominal masih belum disesuaikan dengan inflasi, suku bunga riil yang telah disesuaikan dengan inflasi. 
Kasmir (2014:115) mengatakan faktor - faktor yang mempengaruhi naik turunnya suku bunga diantaranya :

1. Kebutuhan Dana Bank. Apabila bank kekurangan dana, sementara permohonan pinjaman meningkat, maka yang dilakukan oleh bank tersebut agar cepat terpenuhi adalah dengan meningkatkan suku bunga pinjaman. Namun peningkatan suku bunga simpanna juga akan meningkatkan suku bunga pinjaman. Sebaliknya apabila dana yang ada dalam simpanan di bank banyak, sementara permohonan pinjaman sedikit maka bunga simpanan akan turun.

2. Target laba yang diinginkan sesuai dengan target para investor, jika laba yang diinginkan besar, maka bunga pinjaman ikut besar dan sebaliknya.

3. Kualitas Jaminan juga diperuntukkan untuk bunga. Semakin likuid jaminan (mudah dicairkan) yang diberikan, maka semakin rendah bunga kredit yang dibebankan dan demikian sebaliknya.

4. Kebijaksanaan Pemerintah. Dalam arti baik untuk bunga simpanan maupun bunga pinjaman kita tidak boleh melebihi bunga yang sudah ditetapkan oleh pemerintah.

5. Jangka Waktu Simpanan. Baik untuk bunga simpanan maupun bunga pinjaman, faktor jangka waktu sangat menentukan. Semakin panjang jangka waktu pinjaman, semakin tinggi bunganya. Begitupun sebaliknya. Hal ini disebabkan besar kecilnyanya resiko macet dimasa yang akan dating. Akan tetapi untuk bunga simpanan berlaku sebaliknya, semakin panjang jangka waktu maka bunga simpanan semakin rendah dan sebaliknya.

\subsubsection{Harga Saham}

1) Berdasarkan buku Panduan Investasi di Pasar Modal Indonesia, harga sebuah saham sangat dipengaruhi oleh hokum permintaan dan penawaran. Harga saham cenderung naik apabila harga saham mengalami kelebihan permintaan dan cenderung turun jika terjadi kelebihan penawaran.

2) Menurut R. Agus Sartono dalam buku manajemen Investasi (2017:177), harga saham adalah nilai sekarang atau present value dari aliran kas yang diharapkan diterima. Sedangkan menurut Maurice Kendall dalam buku manajemen Investasi (2017:177), harga saham tidak bisa diprediksi atau mempunyai pola tidak tentu. Ia bergerak mengikuti random walk sehingga pemodal harus puas dengan normal return dengan tingkat keuntungan yang diberikan oleh mekasnisme pasar.

Ada dua macam analisis yang banyak digunakan untuk menentukan harga saham, yaitu sebagai berikut :

1. Analisis teknikal, yaitu menentukan harga saham dengan menggunakan data pasar dari saham, misalnya harga saham, volume transaksi dan indeks pasar

2. Analisis fundamental atau analisis perusahaan, yaitu menentukan harga saham dengan menggunakan data fundamental, yaitu data yang berasal dari keuangan perusahaan misalnya laba, deviden yang dibayar, penjualan, pertumbuhan dan prospek perusahaan serta kondisi industri perusahaan.

\subsection{Hubungan Antar Variabel}

\subsubsection{Pengaruh Tingkat Inflasi Dengan Harga Saham}

Inflasi berpengaruh negatif terhadap harga saham karena inflasi meningkatkan biaya suatu perusahaan. Apabila peningkatan biaya lebih tinggi daripada pendapatan perusahaan, maka profitabilitas dari perusahaan tersebut mengalami penurunan. 
Penurunan laba perusahaan akan menyebabkan investor tidak tertarik untuk berinvestasi pada perusahaan, hal ini akan mengakibatkan penurunan harga saham dan berdampak pada penurunan harga saham (Tandelilin, 2010:343). Melihat kondisi seperti ini berarti tingkat inflasi berpengaruh negatif terhadap harga saham.

\subsubsection{Pengaruh Suku Bunga Dengan Harga Saham}

Menurut Tandelilin (2010:214) tingkat suku bunga merupakan proksi bagi investor dalam menentukan tingkat return yang di syaratkan atas surat investasi. Semakin tinggi suku bunga, semakin tinggi pula return yang di syaratkan investor selanjutnya akan berpengaruh harga-harga saham di pasar. Perubahan tingkat suku bunga yang meningkat akan membuat investor menarik investasinya pada saham dan berpindah ke investasi lain berupa tabungan atau deposito.

\subsubsection{Pengaruh Nilai Tukar Dengan Harga Saham}

Depresiasi kurs mata uang domestik terhadap mata uang asing dapat meningkatkan volume ekspor. Hal ini dapat meningkatkan profitabilitas perusahaan yang kemudian meningkatkan harga saham perusahaan apabila permintaan pada pasar international cukup elastis dan mempengaruhi return yang akan di terima oleh investor (Kewal, 2012).

\subsubsection{Pengaruh Inflasi, Suku Bunga dan Nilai Tukar Dengan Harga Saham}

Menurut Maurice Kendall dalam buku manajemen Investasi (2017:177), harga saham tidak bisa diprediksi atau mempunyai pola tidak tentu. Ia bergerak mengikuti random walk sehingga pemodal harus puas dengan normal return dengan tingkat keuntungan yang diberikan oleh mekasnisme pasar. Return saham dapat dipengaruhi oleh faktor inflasi, suku bunga dan nilai tukar. Secara parsial, inflasi, suku bunga dan nilai tukar saling berpengaruh dan berhubungan dengan harga saham. Sedangkan secara simultan, inflasi, suku bunga dan nilai tukar saling berpengaruh dan berhubungan dengan harga saham

\subsubsection{Pengembangan Hipotesis}

Diduga terdapat pengaruh positif tingkat inflasi, suku bunga dan nilai tukar terhadap harga saham studi kasus pada perusahaan manufaktur otomotif yang terdaftar di bursa efek Indonesia tahun 2012 - 2017.

\section{PROSEDUR PENELITIAN}

\subsection{Strategi Penelitian}

Strategi penelitian yang digunakan dalam penelitian ini adalah strategi penelitian asosiatif. Menurut Sugiyono (2014:92) strategi asosiatif merupakan penelitian yang mencari hubungan antara dua variable atau lebih.

\subsection{Populasi dan Sampel Penelitian Populasi penelitian}

Populasi penelitian adalah data inflasi, suku bunga, nilai tukar, dan harga saham sejak PT. Astra Internasional Tbk. go public pada tahun 1990 dan PT. Indomobil Sukses Internasional Tbk. go public pada tahun 1993. 


\section{Sampel penelitian}

Menurut Sugiyono (2014:149) sampel adalah bagian dari jumlah dan karakteristik yang dimiliki oleh populasi tersebut. Bila populasi besar, dan peneliti tidak mungkin mempelajari semua yang ada pada populasi, misalnya karena keterbatasan dana, tenaga dan waktu, maka peneliti dapat menggunakan sampel yang diambilnya dari populasi itu.

Sampel yang akan digunakan peneliti adalah mengambil data inflasi, nilai tukar, suku bunga dan harga saham pada 2 (dua) perusahaan manufaktur otomotif (PT. Astra Internasional Tbk. dan PT. Indomobil Sukses Internasional Tbk.) selama 6 tahun yaitu dari tahun 2012 sampai dengan tahun 2017. Teknik pengambilan sampel adalah purposive sampling. Sample / kriteria dalam penelitian ini adalah : Harga saham perusahaan manufaktur otomotif (PT. Astra Internasional Tbk. dan PT. Indomobil Sukses Internasional Tbk.) selama periode tahun 2012 - 2017.

\subsection{Data dan Metode Pengumpulan Data}

Data dalam penelitian ini menggunakan data sekunder. Sumber pengambilan data inflasi melalui website Badan Pusat Statistik dan Bank Indonesia. Sumber pengambilan data suku bunga melalui website Bank Indonesia. Sumber pengambilan data nilai tukar rupiah/dolar Amerika melalui website Bank Indonesia. Sumber pengambilan data harga saham perusahaan manufaktur otomotif (PT. Astra Internasional Tbk. dan PT. Indomobil Sukses Internasional Tbk.) melalui website perusahaan, website Bursa Efek Indonesia dan website situs analisis saham (www.investing.com).

\subsection{Operasionalisasi Variabel}

Definisi operasional variabel penelitian merupakan penjelasan dari masingmasing variabel yang digunakan dalam penelitian terhadap indikator-indikator yang membentuknya. Operasionalisasi variabel yang diukur dijabarkan kedalam beberapa indicator.

Tabel 1. Operasionalisasi Variabel

\begin{tabular}{|c|c|l|l|}
\hline No. & Variabel & \multicolumn{1}{|c|}{ Definisi } & \multicolumn{1}{c|}{ Pengukuran } \\
\hline 1 & Inflasi & $\begin{array}{l}\text { Tingkat kenaikan harga secara umum. Tingkat inflasi yang } \\
\text { tinggi sering diasosiasikan dengan ekonomi yang "terlalu } \\
\text { panas", yaitu ekonomi dimana permintaan barang dan jasa } \\
\text { lebih tinggi dari kapasitas produksi, sehingga terjadi } \\
\text { kenaikan harga - harga. (Bodie Kane Marcus, 2014:141). }\end{array}$ & Tingkat Inflasi Bulanan \\
\hline 2 & Nilai Tukar & $\begin{array}{l}\text { Nilai tukar dibagi menjadi dua, yaitu nilai tukar nominal } \\
\text { diartikan sebagai nilai yang digunakan seseorang saat } \\
\text { menukar mata uang Negara lain. Sedangkan nilai tukar riil } \\
\text { diartikan sebagai nilai yang digunakan oleh seseorang saat } \\
\text { menukarkan barang dan jasa dari egara lain (Mankiw-Quah } \\
\text { Wilson, 2014:32) }\end{array}$ & Nilai Tukar rata- rata \\
\hline 3 & Suku Bunga & $\begin{array}{l}\text { Bulanan } \\
\text { prinsip konvensional kepada nasabah yang membeli atau } \\
\text { menjual produknya. Bunga juga bisa diartikan harga yang } \\
\text { harus dibayar kepada nasabah dengan yang harus dibayar } \\
\text { oleh nasabah kepada bank. (Kasmir, 2014:114) }\end{array}$ & $\begin{array}{l}\text { Suku Bunga rata - rata per } \\
\text { bulan }\end{array}$ \\
\hline
\end{tabular}




\subsection{Metode Analisis Data}

Metode analisis yang digunakan dalam penelitian ini adalah metode kuantitatif. Analisis data kuantitatif adalah bentuk analisa yang menggunakan angka dan perhitungan statistik. Penelitian ini menggunakan analisis regresi linear berganda, koefisien determinasi dan pengujian hipotesis. Sebelum melakukan pengujian regresi, terlebih dahulu dilakukan uji asumsi klasik untuk mengetahui apakah data yang digunakan telah memenuhi syarat ketentuan dalam model regresi. Uji asumsi klasik yang meliputi uji normalitas, uji autokolerasi, uji heterokedasitas dan uji multikolinearitas.

\subsection{Metode Analisis Statistik}

\section{1) Uji Normalitas}

Menurut Agus Widarjono (2015:78) salah satu asumsi model regresi adalah residual mempunyai distribusi normal. Konsekuensi jika model tidak berdistribusi normal dapat dilihat signifikansi uji t bahwa variabel independen terhadap dependen tidak bisa diaplikasikan.

2) Uji Autokolerasi

Menurut Agus Widarjono (2015:78) Autokolerasi merupakan korelasi antara variabel gangguan satu observasi dengan varian gangguan observasi yang lain. Autokolerasi ini sering muncul pada data time series. Dengan demikian adanya autokorelasi, estimator tidak menghasilkan estimator yang mempunyai varian minimum atau dengan kata lain tidak lagi BLUE.

3) Uji Heterokedastisitas

Pendapat Agus Widarjono (2015:67) Heterokedastisitas berarti varian variabel gangguan yang tidak konstan. Masalah heterokedastisitas dengan demikian lebih sering muncul pada data cross section daripada data time series. Salah satu asumsi metode OLS adalah bahwa varian variabel gangguan sama.

4) Multikolinieritas

Menurut Agus Widarjono (2015:59) Uji multikolinieritas merupakan hubungan linier antara variable independen di dalam regresi berganda. Model regresi yang baik seharusnya bebas multikolinearitas atau idak terjadi kolerasi diantara variable independent.

\subsection{Alat Analisis Data}

1. Analisis Regresi Linear Berganda

Metode ini merupakan suatu analisis yang menjelaskan bentuk pengaruh antara satu variabel atau lebih dengan variabel lainnya dengan persamaan sebagai berikut :

$$
\begin{aligned}
& \hat{\mathrm{Y}}=b_{0}+b_{1} X_{1}+b_{2} X_{2}+b_{3} X_{3} \\
& \text { Keterangan : } \\
& \hat{\mathrm{Y}} \quad=\text { Harga Saham (Rp) } \\
& \mathrm{X}_{1} \quad=\text { Suku Bunga (\%) } \\
& \mathrm{X}_{2} \quad=\text { Inflasi (\%) } \\
& \mathrm{X}_{3} \quad=\text { Nilai tukar (Rp/US\$) }
\end{aligned}
$$

2. Koefisien Determinasi $\left(\mathrm{R}^{2}\right)$

Dalam penelitian ini, peneliti menggunakan $\mathrm{R}^{2}$ adjusted dengan tujuan untuk mengukur besarnya pengaruh variabel bebas $(\mathrm{X})$ terhadap variabel terikat $(\mathrm{Y})$.

\subsection{Pengujian Hipotesis}


Pengujian hipotesis dalam regresi dapat didasarkan pada dua hal, tingkat signifikasi $(\alpha)$ dan tingkat kepercayaan digunakan untuk mengertahui besarnya pengaruh variabel bebas terhadap variabel terikat secara parsial maupun simultan.

1. Uji Hipotesis Secara Parsial

Langkah - langkah pengujian hipotesis secara parsial sebagai berikut :

1) Merumuskan Hipotesis

$H_{0}: \beta_{i}<0 \quad$ (Secara parsial tidak terdapat pengaruh positif dan signifikansi suku inflasi / suku bunga / nilai tukar terhadap harga saham)

$H_{a}: \beta_{i} \geq 0 \quad$ (Secara parsial terdapat pengaruh positif dan signifikansi inflasi / suku bunga / nilai tukar terhadap harga saham)

2) Menentukan taraf nyata $\alpha$ atau tingkat keyakinan $(1-\alpha)$ tarif nyata $(\alpha)$ yang digunakan sebesar 5\% dengan tingkat keyakinan $95 \%$.

3) Menghitung nilai sig. $t$

4) Menentukan daerah kritis (daerah penolakan $H_{0}$ )

$H_{0}$ ditolak, jika sig. $\mathrm{t}<\alpha(0,05)$

$H_{0}$ diterima, jika sig. $t \geq \alpha(0,05)$

2. Uji Hipotesis Secara Simultan

Langkah - langkah pengujian hipotesis secara simultan sebagai berikut :

1) Merumuskan Hipotesis

$H_{0}: \beta_{123}<0 \quad$ (Secara simultan tidak terdapat pengaruh positif dan signifikansi inflasi / suku bunga / nilai tukar terhadap harga saham

$H_{a}: \beta_{123} \geq 0 \quad$ (Secara simultan terdapat pengaruh positif dan signifikansi inflasi / suku bunga / nilai tukar terhadap harga saham)

2) Menentukan taraf nyata $\alpha$ atau tingkat keyakinan $(1-\alpha)$ tarif nyata $(\alpha)$ yang digunakan sebesar 5\% dengan tingkat keyakinan $95 \%$.

3) Menghitung nilai sig. $t$

4) Menentukan daerah kritis (daerah penolakan $H_{0}$ )

$H_{0}$ ditolak, jika sig. $\mathrm{F}<\alpha(0,05)$

$H_{0}$ diterima, jika sig. $\mathrm{F} \geq \alpha(0,05)$

\section{HASIL DAN PEMBAHASAN}

\subsection{Deskripsi Perusahaan}

1. PT. Astra Internasional, Tbk (AUTO)

PT Astra International Tbk didirikan di Jakarta pada tahun 1957 sebagai sebuah perusahaan perdagangan umum dengan nama Astra International Inc. Pada tahun 1990, telah dilakukan perubahan nama menjadi PT Astra International Tbk, dalam rangka penawaran umum perdana saham Perseroan kepada masyarakat, yang dilanjutkan dengan pencatatan saham Perseroan di Bursa Efek Indonesia dengan menggunakan sticker ASII. Nilai kapitalisasi pasar Astra pada akhir tahun 2017 adalah sebesar Rp336,0 triliun.

2. PT. Indomobil Sukses Internasional Tbk. (IMAS)

PT Indomobil Sukses lnternasional Tbk. (Perseroan) merupakan induk dari suatu kelompok usaha otomotif terpadu yang memiliki beberapa anak perusahaan yang bergerak di bidang otomotif yang terkemuka di Indonesia. Perseroan didirikan pada tahun 1976 dengan nama PT Indomobil Investment Corporation dan pada tahun 
1997 dilakukan penggabungan usaha (merger) dengan PT lndomulti Inti lndustri Tbk. dan berubah namanya menjadi PT lndomobil Sukses lnternasional Tbk.

\subsection{Deskripsi Data Penelitian}

1. Analisis Data Inflasi

Menurut Badan Pusat Statistik (BPS), inflasi merupakan kecenderungan naiknya harga barang dan jasa pada umunya yang berlangsung secara terus menerus. Jika inflasi meningkat, maka harga barang dan jasa tersebut menyebabkan turunnya nilai mata uang.

\section{Analisis Data Suku Bunga}

Menurut Kasmir (2014:114) bunga bank dapat diartikan balas jasa yang diberikan oleh bank yang berdasarkan prinsip konvensional kepada nasabah yang membeli atau menjual produknya. Bunga juga bisa diartikan harga yang harus dibayar kepada nasabah dengan yang harus dibayar oleh nasabah kepada bank.

\section{Analisis Data Nilai tukar}

Pendapat yang dikemukan oleh Mankiw-Quah Wilson (2014:32), nilai tukar dibagi menjadi dua, yaitu nilai tukar nominal diartikan sebagai nilai yang digunakan seseorang saat menukar mata uang suatu Negara dengan mata uang negara lain. Sedangkan nilai tukar riil diartikan sebagai nilai yang digunakan oleh seseorang saat menukarkan barang dan jasa dari suatu Negara dengan barang dan jasa dari Negara lain.

\section{Analisis Data Harga Saham}

Menurut Maurice Kendall dalam buku manajemen Investasi (2017:177), harga saham tidak bisa diprediksi atau mempunyai pola tidak tentu. Ia bergerak mengikuti random walk sehingga pemodal harus puas dengan normal return dengan tingkat keuntungan yang diberikan oleh mekasnisme pasar.

\subsection{Hasil Penelitian}

\subsubsection{Uji Asumsi Klasik}

4.3.1.1. Uji Normalitas :

Tujuan dilakukannya pengujian ini adalah untuk menguji bahwa data yang telah ada terdistribusi secara normal atau tidak. Metode ini untuk menguji kenormalitasan data variabel bebas maupun terikat dengan menggunakan uji Kolmogorov-Smirnov. Jika nilai signifikan > taraf nyata $(0,05)$, maka asumsi normalitas akan terpenuhi. Hasil uji normalitas untuk penelitian ini dapat ditampilakn sebagai berikut :

Berdasarkan tabel dibawah hasil dari pengujian Uji Normalitas Kolmogorov-Smirnov terhadap variabel terikat yaitu Harga saham perusahaan manufaktur otomotif menunjukkan bahwa nilai signifikansi sebesar 0,074 yang artinya nilai signifikansi lebih besar dari 0,05, maka dari hasil pengujian Uji Normaitas bahwa data yang digunakan dalam penelitian ini telah terdistribusi secara normal. 
Tabel 2. Hasil Uji Normalitas

\begin{tabular}{|c|c|c|}
\hline \multicolumn{3}{|c|}{ One-Sample Kolmogorov-Smirnov Test } \\
\hline & & $\begin{array}{c}\text { Unstandardized } \\
\text { Residual }\end{array}$ \\
\hline \multicolumn{2}{|l|}{$\mathrm{N}$} & 144 \\
\hline \multirow[t]{2}{*}{ Normal Parameters ${ }^{\mathrm{a}, \mathrm{b}}$} & Mean & .0000000 \\
\hline & Std. Deviation & 2190.92565500 \\
\hline \multirow{3}{*}{$\begin{array}{l}\text { Most Extreme } \\
\text { Differences }\end{array}$} & Absolute & .071 \\
\hline & Positive & .071 \\
\hline & Negative & -.051 \\
\hline \multicolumn{2}{|l|}{ Test Statistik } & .071 \\
\hline \multicolumn{2}{|l|}{ Asymp. Sig. (2-tailed) } & $.074^{\mathrm{c}}$ \\
\hline \multicolumn{3}{|c|}{ a. Test distribution is Normal. } \\
\hline \multicolumn{3}{|l|}{ b. Calculated from data. } \\
\hline c. Lilliefors Significa & Correction. & \\
\hline
\end{tabular}

\subsubsection{Uji Autokorelasi}

Tujuan dari pengujian ini adalah untuk mengetahui apakah dalam model regresi linier ada korelasi antara kesalahan penganggu pada periode $t$ dengan kesalahan penganggu pada periode sebelumnya. Model regresi yang baik adalah model regresi yang bebas dari autokorelasi. Hasil pengujian yang dilakukan oleh penulis sebagai berikut :

Tabel 3. Hasil Uji Autokorelasi

\begin{tabular}{|c|c|}
\hline \multicolumn{2}{|c|}{ Model Summary $^{\mathbf{b}}$} \\
\hline Model & Durbin-Watson $^{|c|} 0.053$ \\
\hline 1 & a. Predictors: (Constant), X3_NILAI TUKAR, X2_BUNGA, X1_INFLASI \\
\hline b. Dependent Variable: Y_HARGA_SAHAM \\
\hline
\end{tabular}

Untuk mendeteksi ada tidaknya autokorelasi dilakukan dengan melakukan uji Durbin-Watson (DW-Test). Berdasrkan tabel diatas dapat diketahui bahwa nilai DurbinWatson sebesar 0,053 . Hal tersebut menunjukkan nilai DW berada diantara -2 dan +2 atau $-2<0,053<+2$, sehingga dapat disimpulkan data penelitian ini tidak mengalami aotokorelasi.

\subsubsection{Uji Heteroskedasitas}

Tujuan dilakukannya pengujian ini adalah untuk melihat apakah model regresi terjadi ketidaksamaan variance dari residual satu pengamatan ke pengamatan lain. Model regresi yang baik adalah yang tidak terjadi heteroskedasitas. Untuk mengidentifikasi ada atau tidak terjadinya heteroskedasitas terhadap penelitian ini adlaah dengan melihat scatterplot antara SPRESID dan ZPRED.

Jika ada pola tertentu, seperti titik - titik yang ada membentuk pola tertentu yang teratur (bergelombang, melebar kemudian menyempit), maka penelitian tersebut terindikasikan terjadi heteroskedasitas. Sedangkan tidak ada pola yang jelas, serta titi titik menyebar di atas dan dibawah angka 0 pada sumbu $\mathrm{Y}$, maka tidak terjadi heteroskedasitas. 


\section{Gambar 1. Hasil Uji Heteroskedasitas Dengan Grafik Scatterplot}

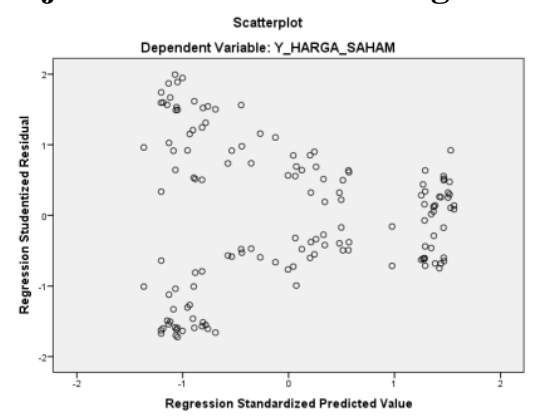

\subsubsection{Uji Multikolonieritas}

Tujuan dilakukannya pengujian ini untuk menguji apakah model regresi dalam penelitian ini ditemukan adanya korelasi antar variabel bebas. Model regresi yang baik adalah yang tidak terjadi multikolonieritas. Untuk mendeteksi adanya multikolonieritas dapat dilihat dari nilai VIF (Variance Inflation Factor) $<20$ atau nilai Toleransi $>0,05$ artinya tidak terjadi multikolonieritas hasil uji dari penelitian ini dapat dilihat sebagai berikut :

Tabel 4.2. Hasil Uji Multikolonieritas

\begin{tabular}{|c|c|c|c|}
\hline \multicolumn{4}{|c|}{ Coefficients $^{\text {a }}$} \\
\hline \multirow{2}{*}{ Model } & \multicolumn{2}{|c|}{ Collinearity Statistiks } \\
\cline { 2 - 4 } & Tolerance & VIF \\
\hline \multirow{4}{*}{1} & X1_INStant) & & \\
\cline { 2 - 4 } & X1_INLASI & 0.803 & 1.245 \\
\cline { 2 - 4 } & X2_BUNGA & 0.81 & 1.235 \\
\cline { 2 - 4 } & X3_NILAI TUKAR & 0.987 & 1.013 \\
\hline \multicolumn{3}{|c|}{ a. Dependent Variable: Y_HARGA_SAHAM } \\
\hline
\end{tabular}

Berdasarkan tabel diatas hasil uji multikolonieritas menunjukkan bahwa semua variabel bebas dalam penelitian ini memiliki nilai tolerance lebih besar dari 0,05 dan nilai VIF lebih kecil dari 20, maka dapat disimpulkan bahwa data yang digunakan dalam penelitian ini tidak terjadi multikolonieritas.

\subsection{2. $\quad$ Analisis Regresi Linier Berganda}

Analisis regresi linier berganda dapat digunakan untuk mengetahui apakah variabel bebas yaitu inflasi (X1), suku bunga (X2) dan nilai tukar (X3) memiliki pengaruh terhadap harga saham sektor manufaktur otomotif. Variabel bebas pada regresi linier ini adalah inflasi (X1), suku bunga (X2) dan nilai tukar (X3) sedangkan variabel terikatnya adalah Harga Saham Perusahaan Manufaktur otomotif (Y). Model regresi berdasarkan analisis diatas. Berdasarkan hasil pengolahan data yang dilakukan penulis maka data yang diperoleh adalah :

Tabel 4 Hasil Regresi Linier Berganda

\begin{tabular}{|l|l|r|r|r|r|r|}
\hline \multicolumn{7}{|c|}{ Coefficients $^{\mathbf{a}}$} \\
\hline \multirow{2}{*}{ Model } & \multicolumn{2}{|c|}{$\begin{array}{c}\text { Unstandardized } \\
\text { Coefficients }\end{array}$} & $\begin{array}{l}\text { Standardized } \\
\text { Coefficients }\end{array}$ & \multirow{2}{*}{ Sig. } & \\
\cline { 3 - 5 } \multicolumn{2}{|l|}{} & \multicolumn{1}{|c|}{ B } & Std. Error & Beta & & \\
\hline \multirow{2}{*}{1} & (Constant) & 10769.406 & 1774.615 & & 6.069 & 0.000 \\
\cline { 2 - 7 } & X1_INFLASI & 5365.671 & 11884.782 & 0.040 & 0.451 & 0.652 \\
\hline
\end{tabular}




\begin{tabular}{|l|l|r|r|r|r|r|}
\hline X2_BUNGA & 93.181 & 177.826 & 0.046 & 0.524 & 0.601 \\
\hline $\begin{array}{l}\text { X3_NILAI } \\
\text { TUKAR }\end{array}$ & -0.510 & 0.114 & -0.354 & -4.478 & 0.000 \\
\hline \multicolumn{7}{|c|}{ a. Dependent Variable: Y_HARGA_SAHAM } \\
\hline
\end{tabular}

Model regresi berdasarkan analisis diatas adalah :

$\mathrm{Y}=10.769,406+5.365,671$ Inlasi + 93.181 Suku Bunga $-0,510$ Nilai Tukar

Interpretasi dari model regresi diatas adalah :

a. Konstanta menunjukkan angka sebesar $10.769,406$ yang mempunyai pengertian bahwa secara matematis harga saham selama periode pengamatan 2012 - 2017 sebesar Rp. 10.769,406 per lembar apabila nilai Inflasi, Suku Bunga dan Nilai Tukar adalah 0 (nol).

b. b1 sebesar 5.365,671 mempunyai arti jika inflasi meningkat sebesar 1\%, maka harga saham naik sebesar Rp. 5.365,671 dengan asumsi tingkat bunga dan nilai tukar konstan

c. b2 sebesar 93.181 mempunyai arti jika suku bunga meningkat sebesar $1 \%$, maka harga saham naik sebesar Rp. 93.181 dengan asumsi inflasi dan nilai tukar konstan

d. b3 sebesar - 0,510 mempunyai arti jika nilai tukar meningkat sebesar Rp. 1/\$, maka harga saham turun sebesar Rp. 0,510 dengan asumsi inflasi dan suku bunga.

\section{Koefisien Determinasi $\left(\mathbf{R}^{2}\right)$}

Koefisien Determinasi (adjusted $\mathrm{R}^{2}$ ) digunakan untuk mengukur seberapa jauh kemampuan model dalam menerangkan variasi variabel terikat. Nilai Koefisien Determinasi (adjusted $\mathrm{R}^{2}$ ) adalah diantara nol (0) dan satu (1). Nilai adjusted $\mathrm{R}^{2}$ yang kecil berarti kemampuan variabel bebas dalam menerangkan variabel bebas terbatas.

Nilai yang mendekati satu berarti variabel bebas memberikan hampir semua informasi yang dibuthkan untuk memprediksi variasi variabel bebas. Hasil koefisien determinasi dalam penelitian dapat dilihat sebagai berikut :

Tabel 5. Hasil Uji koefisien Determinasi

\begin{tabular}{|c|c|c|c|c|}
\hline \multicolumn{5}{|c|}{ Model Summary $^{\mathbf{b}}$} \\
\hline Model & $\mathrm{R}$ & R Square & Adjusted R Square & $\begin{array}{c}\text { Std. Error of the } \\
\text { Estimate }\end{array}$ \\
\hline 1 & $.369^{\mathrm{a}}$ & .136 & .117 & 2214.27543 \\
\hline \multicolumn{4}{|l}{ a. Predictors: (Constant), X3_NILAI TUKAR, X2_BUNGA, X1_INFLASI } \\
\hline
\end{tabular}

Berdasarkan tabel diatas menunjukkan nilai Adjusted R Square sebesar 0,117. Hal ini dapat diartikan bahwa pengaruh inflasi, suku bunga dan nilai tukar terhadap harga saham perusahaan manufaktur otomotif periode 2012 - 2017 sebesar $11,7 \%$ atau jika ditafsirkan dengan kata lain $11,7 \%$ variasi variabel diterangkan oleh inflasi, suku bunga dan nilai tukar. Sedangkan $88,3 \%$ dipengaruhi oleh variabel selain inflasi, suku bunga dan nilai tukar.

\subsubsection{Pengujian Hipotesis Uji Partial (Uji T)}

Uji t digunakan untuk melihat pengaruh variabel - variabel bebas secara individual mempunyai pengaruh terhadap variabel terikatnya. Pengujian ini dilakukan dengan menggunakan signifikansi level $0,05(\alpha=5 \%)$. Hasil perhitungan dalam penelitian ini adalah : 
Tabel 6. Hasil Uji t (Uji Partial)

\begin{tabular}{|c|c|c|c|c|c|c|}
\hline \multicolumn{7}{|c|}{ Coefficients $^{\mathrm{a}}$} \\
\hline & \multirow[t]{2}{*}{ Model } & \multicolumn{2}{|c|}{$\begin{array}{l}\text { Unstandardized } \\
\text { Coefficients }\end{array}$} & \multirow{2}{*}{$\begin{array}{c}\text { Standardized } \\
\text { Coefficients }\end{array}$} & \multirow[t]{2}{*}{$\mathrm{t}$} & \multirow[t]{2}{*}{ Sig. } \\
\hline & & B & Std. Error & & & \\
\hline \multirow[t]{4}{*}{1} & (Constant) & 10769.406 & 1774.615 & & 6.069 & 0.000 \\
\hline & X1_INFLASI & 5365.671 & 11884.782 & 0.040 & 0.451 & 0.652 \\
\hline & X2_BUNGA & 93.181 & 177.826 & 0.046 & 0.524 & 0.601 \\
\hline & $\begin{array}{c}\text { X3_NILAI } \\
\text { TUKAR }\end{array}$ & -0.510 & 0.114 & -0.354 & -4.478 & 0.000 \\
\hline
\end{tabular}

Adapun penjelasan terhadap masing - masing variabel adalah sebagai berikut :

1. Pengujian hipotesis pertama dalam penelitian ini adalah untuk menguji apakah inflasi berpengaruh terhadap harga saham perusahaan manufaktur otomotif. Dari hasil yang didapat dalam penelitian ini menerangkan bahwa koefisien regresi untuk variabel inflasi memiliki signifikansi t sebesar 0,652.

Dengan demikian $\mathrm{H}_{0}$ diterima dan $\mathrm{H}_{\mathrm{a}}$ ditolak karena signifikansi t lebih besar dari $\alpha$ $(0,652>0,05)$ yang berarti inflasi tidak berpengaruh signifkan terhadap harga saham perusahaan manufaktur otomotif.

2. Pengujian hipotesis pertama dalam penelitian ini adalah untuk menguji apakah suku bunga berpengaruh terhadap harga saham perusahaan manufaktur otomotif. Dari hasil yang didapat dalam penelitian ini menerangkan bahwa koefisien regresi untuk variabel suku bunga memiliki signifikansi t sebesar 0.601.

Dengan demikian $\mathrm{H}_{0}$ diterima dan $\mathrm{H}_{\mathrm{a}}$ ditolak karena signifikansi t lebih besar dari $\alpha$ $(0.601>0,05)$ yang berarti suku bunga tidak berpengaruh signifkan terhadap harga saham perusahaan manufaktur otomotif.

3. Pengujian hipotesis pertama dalam penelitian ini adalah untuk menguji apakah nilai tukar berpengaruh terhadap harga saham perusahaan manufaktur otomotif. Dari hasil yang didapat dalam penelitian ini menerangkan bahwa koefisien regresi untuk variabel suku bunga memiliki signifikansi t sebesar 0.000 .

Dengan demikian $\mathrm{H}_{0}$ ditolak dan $\mathrm{H}_{\mathrm{a}}$ diterima karena signifikansi t lebih kecil dari $\alpha$ $(0.000<0,05)$ yang berarti suku bunga berpengaruh signifkan terhadap harga saham perusahaan manufaktur otomotif.

\section{Uji Simultan (Uji F)}

Uji $F$ (uji simultan) digunakan untuk mengetahui seberapa besar pengaruh variabel bebas secara bersamaan (simultan) terhadap variabel terikat. Pengujian dilakukan dengan menggunakan signifikansi level 0,05 $(\alpha=5 \%)$. Hasil perhitungan uji F ini dapat dilihat pada tabel berikut :

Tabel 7. Hasil Uji F (Uji Simultan)

\begin{tabular}{|l|l|l|r|r|r|c|}
\hline \multicolumn{7}{|c|}{ ANOVA $^{\mathrm{a}}$} \\
\hline \multicolumn{2}{|l|}{ Model } & $\begin{array}{c}\text { Sum of } \\
\text { Squares }\end{array}$ & df & Mean Square & F & Sig. \\
\hline \multirow{2}{*}{1} & Regression & 107947536.100 & 3 & 35982512.020 & 7.339 & $.000^{\mathrm{b}}$ \\
\cline { 2 - 7 } & Residual & 686422197.100 & 140 & 4903015.694 & & \\
\cline { 2 - 7 } & Total & 794369733.200 & 143 & & & \\
\hline \multicolumn{2}{|l|}{ a. Dependent Variable: Y_HARGA_SAHAM } \\
\hline \multicolumn{2}{|l}{ b. Predictors: (Constant), X3_NILAI TUKAR, X2_BUNGA, X1_INFLASI } \\
\hline
\end{tabular}


Berdasarkan uji $\mathrm{F}$ pada tabel diatas menunjukkan nilai signifikansi $\mathrm{F}$ sebesar 0,000. Hasil ini dapat disimpulkan bahwa nilai signifikansi lebih kecil dari 0,05, sehingga inflasi, suku bunga dan nilai tukar berpengaruh signifkan terhadap harga saham perusahaan manufaktur otomotif. Dengan kata lain, bahwa $\mathrm{H}_{0}$ ditolak dan $\mathrm{H}_{\mathrm{a}}$ diterima.

\subsubsection{Pembahasan}

4.3.1. Pengaruh Inflasi, Suku Bunga dan Nilai tukar terhadap harga saham

Inflasi, suku bunga dan nilai tukar secara bersama - sama berpengaruh signifkan terhadap harga saham manufaktur otomotif. Hasil tersebut ditunjukkan dengan nilai signifkansi sebesar 0,000, yang dimana jika dibandingkan dengan alpa sebesar 0,05, maka signifikansi t lebih kecil dari $\alpha(0.000>0,05)$.

Hasil penelitian ini serupa dengan penelitian yang dilakukan oleh Yeny Nur Khasanah dan Ari Darmawan (2018), Muhammad Paizal (2017) yang menyatakan bahwa inflasi, suku bunga dan nilai tukar berpengaruh signifikan terhadap harga saham perusahaan otomotif.

\subsubsection{Pengaruh Inflasi terhadap Harga Saham}

Inflasi tidak berpengaruh signifikan terhadap harga saham perusahaan manufaktur otomotif. Hasil tersebut ditunjukkan dengan nilai signifikansi sebesar 0,652, yang dimana jika dibandingkan dengan alpa sebesar 0,05 , maka signifikansi t lebih besar dari $\alpha(0,652$ $>0,05)$.

Inflasi terjadi akibat kenaikan harga-harga secara menyeluruh dan penurunan daya beli konsumen rendah terhadap produk. Tinggi rendahnya inflasi tidak mempengaruhi naik turunnya harga saham pada perusahaan otomotif dikarenakan barang otomotif merupakan barang yang dianggap penting dan menunjukkan kelas dari masyarakat tersebut.

Hasil penelitian ini serupa dengan penelitian yang dilakukan oleh Muhammad Paizal (2017) yang menyatakan bahwa inflasi tidak berpengaruh signifikan terhadap harga saham perusahaan otomotif. Disamping itu, hasil peneelitian ini berbeda dengan Jaja Suteja dan Patrisius Seran (2015), Yeny Nur Khasanah dan Ari Darmawan (2018), yang menyatakan bahwa inflasi berpengaruh signifikan terhadap harga saham perusahaan otomotif.

\subsubsection{Pengaruh Suku Bunga terhadap Harga Saham}

Suku bunga tidak berpengaruh signifikan terhadap harga saham perusahaan manufaktur otomotif. Hasil tersebut ditunjukkan dengan nilai signifikansi sebesar 0,601, yang dimana jika dibandingkan dengan alpa sebesar 0,05 , maka signifikansi t lebih besar dari $\alpha(0,601>0,05)$.

Hal ini diakibatkan adanya konsistensi penurunan yang cukup stabil sehingga nilai suku bunga tidak berpengaruh terhadap saham. Nilai suku bunga yang stabil ini dipengaruhi oleh adanya kebijakan pemerintah agar bisa menyesuaikan suku bunga dipasar. Untuk itu, para investor tidak perlu cemas dikarenakan pemerintah menjamin perubahan suku bunga yang cukup stabil.

Hasil penelitian ini serupa dengan penelitian yang dilakukan oleh Suskim Riantani dan Maria Tambunan (2013), Jaja Suteja dan Patrisius Seran (2015) yang menyatakan bahwa suku bunga tidak berpengaruh signifikan terhadap harga saham. Sedangkan penelitian ini berbeda dengan Yeny Nur Khasanah dan Ari Darmawan (2018), yang menyatakan bahwa suku bunga berpengaruh positif terhadap harga saham perusahaan otomotif. 


\subsubsection{Pengaruh Nilai tukar terhadap Harga Saham}

Nilai tukar berpengaruh signifikan terhadap harga saham perusahaan manufaktur otomotif. Hasil tersebut ditunjukkan dengan nilai signifikansi sebesar 0,000 , yang dimana jika dibandingkan dengan alpa sebesar 0,05 , maka signifikansi t lebih kecil dari $\alpha(0,000$ $<0,05)$.

Hasil penelitian ini serupa dengan penelitian yang dilakukan oleh Yeny Nur Khasanah dan Ari Darmawan (2018), Jaja Suteja dan Patrisius Seran (2015) yang menyatakan bahwa nilai tukar berpengaruh signifikan terhadap harga saham. Sedangkan penelitian ini berbeda dengan Suskim Riantani dan Maria Tambunan (2013), Muhammad Arif Falilah dan Sri Hermuningsih (2017), Jaja Suteja dan Patrisius Seran (2015) yang menyatakan bahwa nilai tukar berpengaruh negatif terhadap harga saham perusahaan otomotif.

\section{SIMPULAN DAN SARAN}

\subsection{Simpulan}

Berdasarkan uraian hasil penelitian pada bab sebelumnya, maka dapat disimpulkan hal-hal sebagai berikut:

1. Secara parsial inflasi dan suku bunga tidak berpengaruh signifikan terhadap harga saham perusahaan manufaktur otomotif. Sedangkan nilai tukar berpengaruh terhadap harga saham perusahaan manufaktur otomotif periode 2012 - 2017.

2. Secara simultan, inflasi, suku bunga dan nilai tukar berpengaruh terhadap harga saham perusahaan manufaktur otomotif periode 2012 - 2017.

3. Nilai Adjusted R Square sebesar 0,117. Hal ini dapat diartikan bahwa pengaruh inflasi, suku bunga dan nilai tukar terhadap harga saham perusahaan manufaktur otomotif periode 2012 - 2017 sebesar $11,7 \%$ dan 88,3\% lainnya dipengaruhi oleh variabel lainnya diluar variabel inflasi, suku bunga dan nilai tukar.

\subsection{Saran}

Berdasarkan kesimpulan hasil penelitian di atas, maka peneliti merekomendasikan saran sebagai berikut:

1. Bagi Perusahaan.

Penelitian membuktikan bahwa secara parsial nilai tukar berpengaruh signifikan positif, artinya setiap perubahan (kenaikan maupun penurunan) nilai tukar sangat mempengaruhi harga saham perusahaan. Untuk itu, setiap adanya fluktuasi nilai tukar, perusahaan harus pintar mencari strategi agar nilai tukar dan harga saham perusahaan bisa terus memberikan dampak yang positif bagi perusahaan.

2. Bagi Peneliti Selanjutnya.

Peneliti selanjutnya diharapkan dapat menambah jumlah variabel independen lain yang tidak ada didalam penelitian ini, dan periode waktu agar didapatkan hasil penelitian yang kompherensif.

\section{DAFTAR PUSTAKA}

Bank Indonesia. Data Inflasi Indonesia, diunduh tanggal 08 Agustus 2018, www.bi.go.id.

Bank Indonesia. Data Suku Bunga Indonesia, diunduh tanggal 08 Agustus 2018, www.bi.go.id.

Badan Pusat Statistik. Data Inflasi Indonesia, diunduh tanggal 08 Agustus 2018, www.bps.go.id. 
Badan Pusat Statistik. Data Suku Bunga Indonesia, diunduh tanggal 08 Agustus 2018, www.bps.go.id.

Blanchard, Olivier dan David R. Johnson. 2017. Makroekonomi edisi keenam. Jakarta. Erlangga.

Bodie, Kane dan Marcus. 2014. Manajemen Portofolio dan Investasi (Investment). Jakarta: Salemba Empat.

Brigham and Houston. 2010. Dasar-dasar Manajemen Keuangan. Edisi 11. Jakarta. Salemba Empat.

Bursa Efek Indonesia. Saham PT. Astra Internasional Tbk. dan PT. Indomobil Sukses Internasional Tbk., diunduh tanggal 08 Agustus 2018, www.idx.co.id.

Darmawan, Harris. 2017. Kenali apa itu analisis fundamental, beserta rasio keuangan penting yang dipakai dalam berinvestasi saham. Diunduh tanggal 25 maret 2018, http://finansialku.com.

Falilah, Muhammad Arif dan Sri Hermuningsih. 2017. Pengaruh Nilai Tukar dan Harga Minyak Mentah Dunia Terhadap Return Saham PT. Indomobil Sukses Internasional Tbk. Dan PT. Astra Internasional Tbk. Tahun 2006-2016. Universitas Sarjahawiyata Tamansiswa. Vol 1. No 2, 2017.

Ghozali, Imam. 2016. Aplikasi Analisis Multivariate Dengan Program IBM. Universitas Diponegoro. Semarang.

Gibson, Charles H. 2001. Financial Reporting and Analysis Using Financial Accounting Information. Eight Edition. Ohio : South Western College.

Gumanti, Tatang Ari. 2013. Manajemen Investasi Konsep, Teori dan Aplikasi. Mitra Warana Media. Jakarta

Halim, Abdul. 2015. Analisis Investasi di Aset Keuangan. Jakarta : Mitra Wacana Media.

Hery. 2017. Analisis Laporan Keuangan Integrated and Comprehensive Edition. Jakarta : PT Gramedia Widiasarana Indonesia, 2017.

Hunjra, et al. 2014. Impact of Dividend Policy, Earning Per Share, Return on Equity, Profit after Tax on Stock Prices. International Journal of Economics and Empirical Research. 2 (3), 109 - 115.

Investing. Data Harga PT. Astra Internasional Tbk. dan PT. Indomobil Sukses Internasional Tbk., diunduh tanggal 08 Agustus 2018, www.investing.com.

Jogiyanto. (2011). Teori Portofolio dan Analisis Investasi Edisi 7. Yogyakarta: BPFEYogyakarta.

Kasmir. 2014. Bank dan Lembaga Keuangan Lainnya Edisi Revisi 2014. Rajawali. Jakarta

Khasanah, Yeny Nur dan Ari Darmawan, 2018. Pengaruh Risiko Inflasi, Risiko Suku Bunga, Risiko Kurs Valuta Asing, Dan Leverage Terhadap Return Saham, Vol. 57 No.1. 
Khoury , Rim M. El. 2017. Do macroeconomic factors matter for stock returns? Evidence from the European automotive industry. Jurnal Ekonomi dan Keuangan Internasional. 1752-0479

Mankiw, N. Gregory., Euston Quah and Peter Wilson. 2014. Pengantar Ekonomi Makro. Salemba Empat. Jakarta

Paizal, Muhammad. 2017. Pengaruh Makro Ekonomi dan Mikro Perusahaan Terhadap Harga Saham Perusahaan Sub Sektor Otomotif yang Terdaftar di Bursa Efek Indonesia Periode 2012-2015. Vol 1 No. 1, 2017

Putong, Iskandar. 2013. Ekonomi, Pengantar Mikro / Makro. Mitra Wacana Media. Jakarta

Riantani, Suskim dan Maria Tambunan. 2013. Analisis Pengaruh Variabel Makroekonomi dan Indeks Global terhadap Return Saham pada Industri Otomotif. SEMANTIK 2013 Universitas Widyatama Bandung. ISBN: 979-26-0266-6.

Ross, Stephan. et al. 2015. Pengantar Keuangan Perusahaan. Salemba Empat. Jakarta.

Samsul, Mohammad. 2015. Pasar Modal Dan Manajemen Portofolio. Erlangga. Jakarta

Sugiyono. 2014. Metode Penelitian Pendidikan. Bandung : Alfabeta.

Sukirno, Sadono. 2013. Mkaroekonomi Teori Pengantar, Raja Grafindo Persada. Jakarta

Sumodiningrat, Gunawan. 2015. Ekonometrika Pengatar. Yogyakarta : Fakultas Ekonomika dan Bisnis UGM

Sunariyah. 2011. Pengantar Pengetahuan Pasar Modal. Edisi Kelima. Yogyakarta : Sekolah Tinggi Ilmu Manajemen YKPN.

Suteja, Jaja dan Patrisius Seran. 2015. Determinan Return Saham Industri Otomotif dan Komponen yang Terdaftar di BEI. Universitas Pasundan. ISSN 2355-7737.

Widiarjono, Agus. 2015. Analisis Multivariat Terapan Dengan Program SPSS, AMOS dan SMARTPLS. Edisi Kedua. Yogyakarta : UPP STIM YPKN

Tandelilin, Eduardus. 2017. Portofolio dan Investasi (teori dan aplikasi). Edisi Pertama. Yogyakarta: Kanisius.

Yaniawati, dan Indrawan. 2016. Metodologi Penelitian Kuantitatif, Kualitatif, dan Campuran (untuk Manajemen, Pembangunan, Pendidikan). Edisi Kedua. Bandung : Refika Aditama. 